\title{
PERCOBAAN APLIKASI PEMBANGKIT GELEMBUNG MIKRO UNTUK MENURUNKAN KANDUNGAN ZAT BESI DALAM AIR TANAH
}

\author{
Robertus Haryoto Indriatmoko, Arie Herlambang dan Rudi Nugroho \\ Pusat Teknologi Lingkungan, BPPT, Kawasan Puspiptek, Tangerang Selatan, 15314, Indonesia \\ E-mail: robertus.haryoto@bppt.go.id ; arie.herlambang@bppt.go.id ; rudi.nugroho@bppt.go.id
}

\begin{abstract}
ABSTRAK
Penggunaan air tanah sebagai sumber air bersih untuk digunakan sebagai air minum sering terkendala oleh kualitas air mengandung besi terlarut yang cukup tinggi. Kandungan zat besi diatas $0,3 \mathrm{ppm}$ menyebabkan sumber air tersebut tidak layak digunakan sebagai sumber air baku air bersih dan untuk kandungan besi diatas $0,05 \mathrm{ppm}$ menyebabkan sumber tersebut tidak layak digunakan sebagai sumber air minum. Air baku dengan kualitas seperti itu sebaiknya dilakukan pengolahan terlebih dahulu. Air tanah yang berasal dari daerah vulkanik aktif dengan batuannya banyak mengandung zat besi terutama dari daerah yang sering mengalami perendaman air seperti daerah bekas sawah atau bekas rawa. Proses kimiawi yang bekerja di wilayah ini tersebut pada umumnya adalah proses reduksi. Pada umumnya besi yang ada terlarut dalam air adalah sebagai $\mathrm{Fe}^{2+}$ atau $\mathrm{Fe}^{3+}$, dalam ikatan kimia sebagai $\mathrm{Fe}_{2} \mathrm{O}_{3}, \mathrm{Fe}(\mathrm{OH})_{2}$ $\mathrm{Fe}(\mathrm{OH}) 3$ ataunFeSO${ }_{4}$. Setelah dilakukan ekploitasi atau pengambilan air tanah dan air baku tersebut mengalami kontak langsung dengan udara, maka akan berwana kecoklatan, berbau amis seperti karat besi. Ada tiga cara penurunan zat besi dalam air yaitu dengan cara 1. Aerasi, 2. Sedimentasi dan 3. Filtrasi. Dalam percobaan ini proses penurunan zat besi dilakukan dengan cara aerasi yaitu dengan mengaplikasikan penggunaan gelembung mikro yang dihasilkan dari generator pembangkit gelembung mikro dan dengan filtrasi. Pembangkit gelembung micro ini dibangkitkan oleh pompa KTN Merk Nikuni menghasilkan gelembung udara dengan diameter 20 micron yang digunakan sebagai bahan oksidator untuk air baku mengandung besi. Setelah proses oksidasi berlangsung dalam periode waktu tertentu kemudian disaring dan diukur sisa kandungannya. Hasil percobaanadalah pada kandungan besi dalam air baku sebesar 1,16 ppm yang direaksikan dalam sebuah reactor maka efisiensi oksidasi dapat dicapai dengan baik dan berhasil menambah kelarutan oksigen dalam air sebesar 71-80 \% dan menurunkan zat besi dalam air baku sampai mencapai 38-56 \% pada $\mathrm{pH}$ 7. Kesimpulan yang dapat diambil melalui percobaan ini adalah bahwa generator gelembung mikro mampu digunakan sebagai sebuah cara untuk mengoksidasi zat besi terlarut dalam air baku dan dapat dimanfaatkan sebagai sebuah cara untuk meningkatkan kandungan oksigen terlarut air baku.
\end{abstract}

Kata kunci: air tanah, zat besi terlarut, pembangkit gelembung mikro, oksidasi

\section{EXPERIMENT OF THE APPLICATION OF THE MICRO BUBBLE GENERATOR TO REDUCE IRON CONTENT IN RAW WATER}

\author{
Robertus Haryoto Indriatmoko, Arie Herlambang and Rudi Nugroho \\ Center for Environmental Technology, BPPT, Puspiptek Area, South Tangerang, 15314, Indonesia \\ E-mail: robertus.haryoto@bppt.go.id ; arie.herlambang@bppt.go.id ; rudi.nugroho@bppt.go.id
}

\begin{abstract}
The use of ground water as a source of raw water for use as drinking water is often constrained by the high quality of water containing dissolved iron. Iron content above $0.3 \mathrm{ppm}$ causes the source of water not suitable to be used as a source of raw water for clean water and for iron content above $0.05 \mathrm{ppm}$ this source is not suitable to be used as a source of drinking water. Raw water with such quality should be processed first. Groundwater originating from active volcanic regions with many rocks containing iron, especially from areas that often experience immersion in water such as former fields or former swamps. The chemical process that works in this area is generally a reduction process. In general, iron that is dissolved in water is $\mathrm{Fe}^{2+}$ or $\mathrm{Fe}^{3+}$, in chemical bonds as $\mathrm{Fe}_{2} \mathrm{O}_{3}, \mathrm{Fe}(\mathrm{OH})_{2} \mathrm{Fe}(\mathrm{OH})_{3}$ or $\mathrm{FeSO}_{4}$. After exploitation or extraction of ground water and the raw water is in direct contact with air, it will be brownish, fishy like iron rust. There are three ways to reduce iron in water by 1. Aeration, 2. Sedimentation and 3. Filtration. In this experiment the process of reducing iron was carried out by aeration by applying the use of micro bubbles generated from micro bubble generator generators and by filtration. This micro bubble generator is generated by KTN pumps. Nikuni produces air bubbles with a diameter of 20 microns which are used as oxidizing agents for iron-containing raw water. After the oxidation process takes place over a period of time then filtered and
\end{abstract}


measured the remaining content. The experimental results are in the iron content in raw water of 1.16 ppm which is reacted in a reactor so that the oxidation efficiency can be achieved well and successfully increase the solubility of oxygen in the water by $71-80 \%$ and reduce iron in raw water until it reaches $38-56 \%$ at $\mathrm{pH}$ 7. The conclusion that can be drawn from this experiment is that micro bubble generators can be used as a way to oxidize dissolved iron in raw water and can be used as a way to increase the dissolved oxygen content of raw water.

Keywords: groundwater, dissolved iron, generator micro bubble, oxidation 


\section{PENDAHULUAN}

Kendala kualitas air baku untuk sumber air bersih yang digunakan sebagai sumber penyediaan air bersih pada wilayah yang jauh dari jangkauan PDAM yang utama dan banyak dijumpai di dalam manyarakat adalah adanya kandungan besi tinggi pada sumber-sumber tersebut. Sementara itu penyediaan air bersih yang dilakukan oleh PDAM masih terpusat di kotakota, padahal masyarakat yang membutuhkan sumber air tersebut bukan hanya dikota namun di desa dan daerah terpencil yang jauh dari jangkauan PDAM.

Saat ini cakupan air bersih di Indonesia (2014) baru mencapai 68 persen dan ditargetkan pada tahun 2019 mencapai 76,2 persen, meskipun cakupan pelayanan sudah semakin luas namun bagi masyarakat yang tinggal di pulau terpencil, masyarakat yang tinggal di pesisir pantai dan muara sungai dan masyarakat yang tinggal di daerah rawa - rawa dan di wilayah gambut tetap perlu mendapat perhatian. Untuk mendapatkan sumber air bersih di wilayahwilayah tersebut pada umumnya mereka terkendala oleh kualitas air baku yang pada umumnya mengandung besi tinggi, asam dan warna air yang coklat.

Masyarakat yang tinggal di wilayah yang telah disebutkan sebelumnya, untuk mendapatkan sumber air baku disamping menggunakan sumber air permukaan mereka juga mengambil sumber air dari tanah dan air hujan juga mata air. Sumber air tanah yang diperoleh dari wilayah tersebut pada umumnya juga kurang baik dimana air tanah yang berasal dari wilayah berawa, muara dan pinggir sungai yang alirannya sering tergenang pada umumnya mengandung zat besi (Fe) dan Mangan (Mn) cukup besar.

Kandungan Fe dan Mn dalam air tanah dapat menyebabkan warna air tersebut berubah menjadi kuning-coklat setelah beberapa saat kontak dengan udara. Kualitas air semacam ini jika dikonsumsi dapat menyebabkan gangguan terhadap kesehatan manusia disamping warna coklat yang mengganggu adanya bau yang tidak enak amis dan berbau karat, air dengan kualitas semacam itu dapat menyebabkan warna kuning pada dinding bak serta bercak-bercak kuning pada pakaian.

Kandungan zat besi dan Mangan dalam air baku tersebut pada umumnya berkisar antara 124 ppm. Konsentrasi besi dan mangan dalam air dengan kadar sebesar 1-24 ppm tersebut pada umumnya sudah menimbulkan gangguan yang cukup serius baik untuk digunakan sebagai air bersih maupun sumber air minum yaitu timbulnya warna coklat, bau amis dan bau karat dan dapat menimbulkan gangguan pada kesehatan manisua.
US-EPA telah menetapkan bahwa untuk kandungan zat besi untuk air bersih adalah 0,3 $\mathrm{mg} / \mathrm{l}$ (ppm) dan air minum adalah 0,05 mg/l. Sedangkan menurut Standard kesehatan berdasarkan Keputusan Menteri Kesehatan Republik Indonesia Nomor 907/MENKES/ SK/VII/2002, kandungan zat besi yang diperbolehkan maksinum adalah 0,3 mg/l (ppm) sedangkan kadar mangan maksimum adalah $0,1 \mathrm{mg} / \mathrm{l}$.

Sadar akan adanya kadar besi yang ditetapkan dalam air baku untuk air minum yang begitu ketat maka hal tersebut menjadi dasar yang kuat bagi diterapkannya sebuah percobaan untuk mendapatkan air baku yang sesuai dengan standar kualitas yang ditetapkan.

Maka dibuatlah sebuah percobaan untuk menurunkan kandungan akan zat besi terlarut dalam air. Salah satu cara menurunkan zat besi dan mangan terlarut dalam air dilakukan dengan cara mengkontakan air baku dengan udara caranya adalah dengan menyemprotkan melalui sprayer air baku kedalam bak penampung air baku.

Berdasarkan motode yang telah diuraikan di atas maka dilakukanlah sebuah percobaan oksidasi air baku mengandung larutan besi dengan cara mengaplikasikan sebuah pembangkit gelembung mikro kedalam reactor yang air baku, maka pencampuran antara gelembung mikro dan air baku mengandung zat besi tinggi kedalam sebuah reaktor akan menyebabkan gelembung udara tersebut mengoksidasi zat besi yang terlarut dalam air. Sistem yang dibangun untuk proses oksidasi tersebut seperti yang digambarkan dalam rangkaian percobaan Gambar 1.

\section{TUJUAN dan SASARAN}

Tujuan dilakukannya percobaan ini adalah:

a. Untuk mengaplikasikan sistem oksidasi yang berasal dari gelembung mikro yang diinjeksikan kedalam tabung reaktor.

b. Untuk menguji efisiensi sebuah oksidasi yang dilakukan dengan gelembung mikro.

\section{BAHAN DAN METODE}

\subsection{Bahan}

Bahan yang digunakan untuk percobaan ini terdiri dari:

a. Sistem rangkaian percobaan menggunakan disain seperti rangkaian dalam Gambar 1.

b. Bahan yang digunakan terdiri dari:

- Tangki air baku volume $5 \mathrm{~m}^{3}$.

- Pompa dosing untuk memompakan larutan kapur.

- Pompa Nikuni (sebagai generator gelembung mikro). 
- tangki reactor volume diameter $60 \mathrm{x}$ $250 \mathrm{~cm}$.

- $\mathrm{pH}$ meter.

- Flow meter (debit meter).

- Tangki penampung air hasil olahan.

- Air baku dengan kandungan zat besi dengan kadar diatas 3 ppm.
C. Tempat percobaan dilakukan di laboratorium Geostek BPPT dengan menggunakan anggaran biaya pada tahun anggaran 2016.

Cara atau metode percobaan dilakukan dengan menggunakan system batch dan proses sampling dilakukan dengan interfal waktu. Variabel perubahan debit air baku dan volume udara oksidasi.

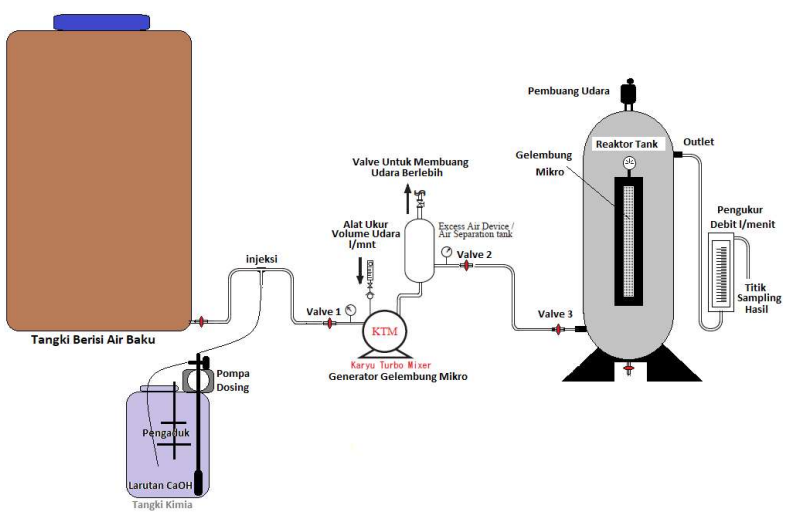

Gambar 1: Rangkaian Alat Untuk Percobaan

Rancangan sistem peralatan percobaan seperti dalam gambar 1. Sedangkan cara kerja dilakukannya percobaan adalah sebagai berikut:

\subsection{Metode}

Pada percobaan ini proses aerasi dilakukan dengan mereaksikan udara dengan gelembung mikro dengan air baku mengandung larutan besi tinggi dalam sebuah reaktor. Air baku yang dioksidasi dengan menggunakan gelembung udara mikro dengan diameter 20 micron ini terlebih dahulu diatur $\mathrm{pH}$ air baku pada $\mathrm{pH} 7$.

Proses oksidasi di dalam reaktor ini akan mengontakkan oksigen air agar zat besi atau mangan yang ada di dalam air baku berreaksi dengan oksigen. Reaksi ini akan membentuk senyawa ferri ( $\mathrm{Fe}$ valensi 3 ) serta mangan oksida yang relatif tidak larut di dalam air.

Umumnya makin tinggi $\mathrm{pH}$ air kecepatan reaksi oksidasinya makin cepat. Kadang-kadang perlu waktu tinggal sampai beberapa jam setelah proses aerasi agar reaksi berjalan tergantung dari karakteristik air bakunya.

$\mathrm{Di}$ dalam proses penghilangan besi dan mangan dengan cara aerasi, adanya kandungan alkalinity, ( $\mathrm{HCO} 3)^{-}$yang cukup besar dalam air, akan menyebabkan senyawa besi atau mangan berada dalam bentuk senyawa ferro bikarbonat, $\mathrm{Fe}\left(\mathrm{HCO}_{3}\right)_{2}$ atau mangano bikarbonat, $\mathrm{Mn}\left(\mathrm{HCO}_{3}\right)_{2}$. Oleh karena bentuk $\mathrm{CO}_{2}$ bebas lebih stabil daripada (HCO3)', maka senyawa bikarbonat cenderung berubah menjadi senyawa karbonat.

$\mathrm{Fe}(\mathrm{HCO} 3)_{2}===>\mathrm{FeCO}_{3}+\mathrm{CO}_{2}+\mathrm{H}_{2} \mathrm{O}$

$\mathrm{Mn}(\mathrm{HCO} 3)_{2}===>\mathrm{MnCO}_{3}+\mathrm{CO}_{2}+\mathrm{H}_{2} \mathrm{O}$
Dari reaksi tersebut dapat dilihat, jika $\mathrm{CO}_{2}$ berkurang, maka kesetimbangan reaksi akan bergeser ke kanan dan selanjutnya reaksi akan menjadi sebagai berikut :

$$
\begin{aligned}
& \mathrm{FeCO}_{3}+\mathrm{CO}_{2}===>\mathrm{Fe}(\mathrm{OH})_{2}+\mathrm{CO}_{2} \\
& \mathrm{MnCO}_{3}+\mathrm{CO}_{2}===>\mathrm{Mn}(\mathrm{OH})_{2}+\mathrm{CO}_{2}
\end{aligned}
$$

Baik hidroksida besi (valensi 2) maupun hidroksida mangan (valensi 2) masih mempunyai kelarutan yang cukup besar, sehingga jika terus dilakukan oksidasi dengan udara atau aerasi akan terjadi reaksi (ion) sebagai berikut :

$$
\begin{aligned}
& 4 \mathrm{Fe}^{2+}+\mathrm{O}_{2}+10 \mathrm{H}_{2} \mathrm{O}===>4 \mathrm{Fe}(\mathrm{OH})_{3}+8 \\
& \mathrm{H}^{+} \\
& 2 \mathrm{Mn}^{2+}+\mathrm{O}_{2}+2 \mathrm{H}_{2} \mathrm{O}===>2 \mathrm{MnO}_{2}+4 \\
& \mathrm{H}^{+}
\end{aligned}
$$

Sesuai dengan reaksi tersebut, maka untuk mengoksidasi setiap $1 \mathrm{mg} / \mathrm{l}$ zat besi dibutuhkan $0,14 \mathrm{mg} / \mathrm{l}$ oksigen dan setiap $1 \mathrm{mg} / \mathrm{l}$ mangan dibutuhkan $0,29 \mathrm{mg} / \mathrm{l}$. Pada $\mathrm{pH}$ rendah, kecepatan reaksi oksidasi besi dengan oksigen (udara) relatif lambat, sehingga pada prakteknya untuk mempercepat reaksi dilakukan dengan cara menaikkan $\mathrm{pH}$ air yang akan diolah.

Dalam percobaan ini air tanah dangkal dipompa dari kedalaman 13 meter, kemudian ditampung dalam bak penampung sebesar $5 \mathrm{~m} 3$, air dengan kandungan zat besi dipompa dengan terlebih dahulu dilakukan pengaturan $\mathrm{pH}$ sesuai dengan yang dikehendaki dengan menggunakan soda ash.

Air dalam debit tertentu dialirkan dengan pompa pembangkit gelembung mikro setelah 
terlebih dahulu diinjeksi dengan larutan kapur $\mathrm{CaOH}$, sehingga air baku akan masik kedalam reactor bercampur dengan gelembung mikro (Lihat Gambar 1). Proses reaksi akan terjadi dalam tabung reactor dan reaksi ini akan terjadi dalam waktu tinggal tertentu tergantung dari besarnya debit air yang di masukkan kedalam rector.

Untuk mengetahui efisiensi dari reaksi maka dilakukan percobaan dengan merubah besarnya debit input dan dicari hubungan antara waktu tinggal dengan penurunan konsentrasi Fe dalam air

\section{HASIL DAN PEMBAHASAN}

4.1. Hasil
Penelitian yang dilakukan Tatsumi Iwao (1971) tentang penurunan zat besi dalam air tanah, setelah dilakukan proses aerasi dengan waktu tinggal tertentu menunjukkan adanya penurunan zat besi sejalan dengan lamanya waktu aerasi dan naiknya pH larutan (Gambar 2).

Pada penelitian ini, kandungan besi dalam air tanah cukup rendah, yaitu 0,16 mg/liter, oleh karena itu untuk keperluan percobaan digunakan zat tambahan yang berupa fero sulfat $\left(\mathrm{FeSO}_{4}\right.$ $\mathrm{xH}_{2} \mathrm{O}$ ). Dalam proses penambahan ini terjadi kesulitan, karena pada proses percampuran dilakukan dipermukaan, sehingga terjadi oksidasi dari udara sekitarnya dan larutan berubah menjadi Feri sulfat $\left(\mathrm{Fe}_{2}\left(\mathrm{SO}_{4}\right)_{3} \mathrm{xH}_{2} \mathrm{O}\right)$ yang warnanya merah kekuningan dan bersifat lebih stabil. Kondisi ini menghambat penurunan zat besi dalam air olahan.

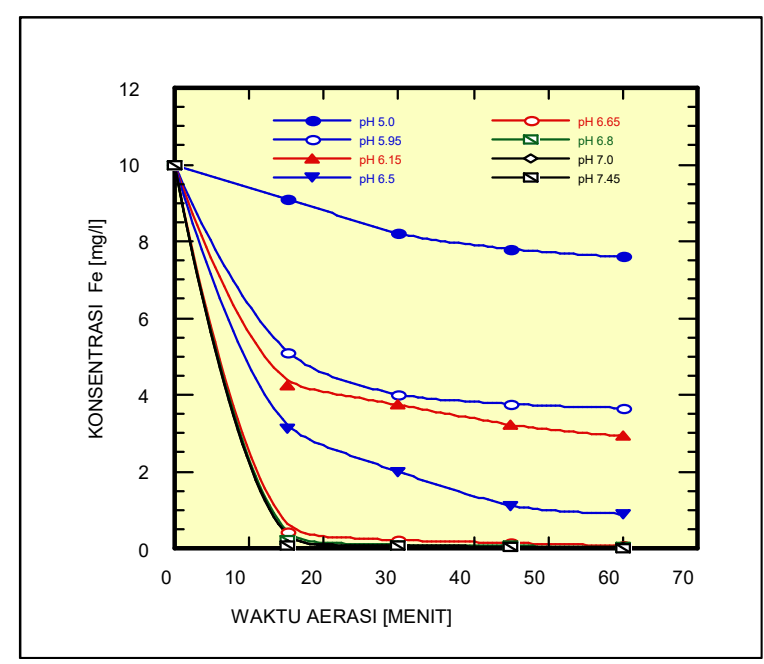

Gambar 2: Penurunan zat besi dalam air tanah fungsi pH dan waktu aerasi (Sumber: Tatsumi Iwao, 1971).

\section{Percobaan 1}

Percobaan Teknologi Gelembung Mikro digunakan debit aliran 15 liter/menit, dengan debit udara 5 liter/menit, dengan waktu reaksi kontak 60 menit. Berhasil menaikkan kandungan oksigen dalam air berhasil menaikkan kandungan oksigen terlarut 73 - 81\%. Ini menunjukkan efektifitas penggunaan gelembung mikro dalam meningkatkan kandungan oksigen terlarut.

Peningkatan oksigen terlarut dalam air baku ini diharapkan juga akan bermanfaat dalam mengoksidasi larutan besi dalam air baku sehingga kualitas air baku akan meningkat dengan adanya peningkatan oksigen dalam air ini. Lihat hasil percobaan pada Gambar 2. 


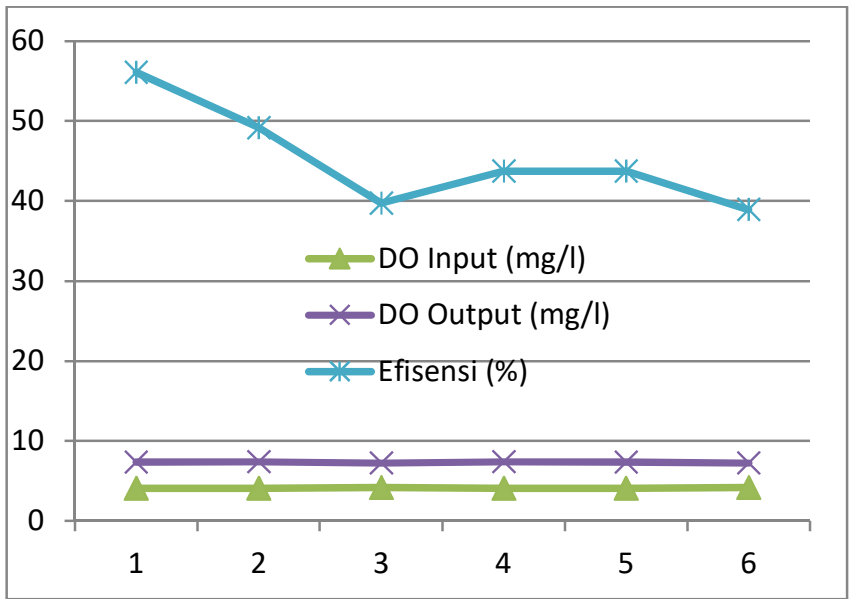

Gambar 2.: Kenaikkan kelarutan oksigen yang berkisar $71-81 \%$ pada reactor skala lab.

Hasil percobaan aplikasi pembangkit gelembung mikro dalam air baku mengandung besi ternyata juga berhasil menurunkan kandungan zat besi dalam air, seperti yang terlihat pada Gambar 3, dimana pada $\mathrm{pH} 7$, kandungan besi dalam air baku juga mengalami penurunan yang sangat signifikan.

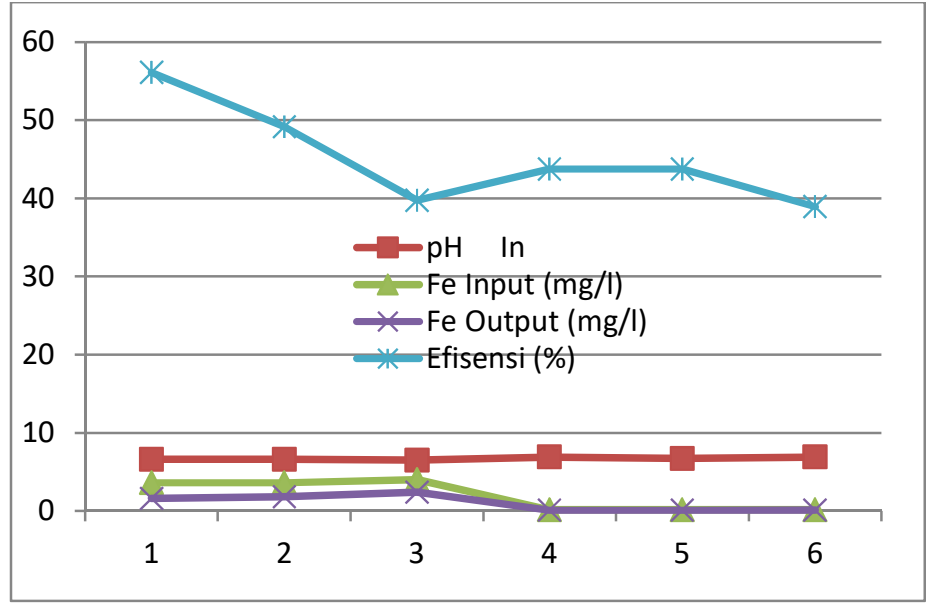

Gambar 3: Efisiensi penurunan zat besi yang berkisar $38-56 \%$.

\subsection{Pembahasan}

Hasil percobaan ini jika dibandingkan dengan percobaan yang dilakukan oleh Tatsumi Iwao nampaknya dapat menghasilkan hasil yang kurang lebih sama meskipun pada range konsentrasi air baku yang berbeda, Tatsumi Iwao memulai percobaannya dimulai pada saat kandungan zat besi terlarut dalam air mencapai 10 ppm sedangkan percobaan ini memulai rang konsentrasinya pada 1,16 ppm.

Meskipun ratio penurunan yang dilakukan oleh Tatsumu Iwsao lebih tinggi terhadap hasil akhir, namun pada konsentrasi zat besi yang rendah, penurunan yang terjadi relative sama. Artinya ratio penurunan berada pada ratio yang sama.

Dalam percobaan yang dilakukan oleh Tatsumi Iwao pada awal konsentrasi zat besi terlarut dalam air sangatlah tinggi yaitu pada 10 $\mathrm{mg} / \mathrm{lt}$ dan pada waktu tinggal atau lama reaksi sekitar 20 menit, konsentrasi zat besi dalam air sudah mencapai kurang dari 0,5 mg/l.

Hasil percobaan yang dilakukan oleh Tatsumi Iwao pada menit yang ke 50 juga menunjukkan bahwa konsentrasi zat besi yang larut dalam air juga mengalami penurunan menjadi sangat kecil, mungkin kurang dari 0,1 mg/l.

Kelebihan lain dari percobaan yang dilakukan oleh Tatsumi Iwao adalah bahan baku yang digunakan dicobakan dalam berbagai $\mathrm{pH}$ yang berbeda, mulai dari $\mathrm{pH} 5$ sampai $\mathrm{pH}$ 7,5 dari situ kelihatan bahwa efisiensi penurunan kadar besi terlarut dalam air yang paling efisioen adalah pada $\mathrm{pH}$ diatas 7.

Pada percobaan ini konsentrasi zat besi terlarut dalam air adalah 1,16 ppm dimana ini 
sudah melebihi dari konsentrasi yang dibolehkan sebagai air baku air bersih.

Pada awalnya kami merencanakan percobaan akan dilakukan dengan melarutkan ferro sulfat ke dalam air baku dengan harapan dapat diperoleh berbagai konsentrasi zat besi berbeda dalam setiap air baku, sehingga akan diperoleh air baku buatan dengan konsentrasi zat besi terlarut dalam air sebesar 5 ppm, 4 ppm, 3 ppm, 2 ppm, 1ppm. Namun percobaan ini batal dilakukan karena pada pada percobaan dalam skala kecil tidak menghasilkan hasil yang signifikan.

Akhirnya percobaan dilakukan dengan menggunakan air tanah dengan konsentrasi zat nesi terlarut dalam air sebesar $1,16 \mathrm{ppm}$ dan hasil percobaan telah diperlihatkan pada Gambar 2 dan Gambar 3.

Percobaan dengan menggunakan system oksidasi gelembung mikro ini terlihat memiliki kelebihan jika system oksidasi dilakukan ngan menggunakan system air baku yang di sparyerkan sehingga menjadi butir air sehingga air akan kontak langsung dengan udara, ternyata penggunaan gelembung mikro yang dicampurkan secara langsung kedalam tangki reactor adalah kelarutan oksigen dalam air baku akan meningkat 73-80 \% sehingga akan dapat memperbaiki kualitas air baku dalam penyerapan oksigen sehingga disamping akan digunakan sebagai sumber oksidasi bagi zat besi terlarut dalam air oksigen akan digunakan dalam mengoksidasi zatzat lainnya seperti untuk biologi dan kimia.

Air yang kelarutan oksigen dalam air besar maka air tersebut akan menjadi air yang sehat. Oksigen ini akan digunakan sebagai self purification untuk memperbaiki kualitasnya secara sendiri.

\section{KESIMPULAN}

Kesimpulan yang dapat diambil dari hasil percobaan ini adalah:

a. Pengaplikasian pembangkit gelembung mikro dapat digunakan sebagai cara untuk mengoksidasi secara langsung kedalam air baku zat besi dan mangan terlarut dalam air.

b. Meningkatkan konsentrasi oksigen terlarut dalam air baku.

c. Sistem ini dapat diaplikasikan dalam pretreatmen dari sebuah unit pengolahan air.

\section{SARAN}

Perlu dilakukan kajian ekonomi terhadap pembangkit gelembung mikro sebab 1 Unit Pembangkit gelembung mikro saat ini masih tergolong mahal. Sehingga perlu dilakukan inovasi untuk menciptakan alat dengan kemampuan yang sama namun harganya murah.

\section{UCAPAN TERIMA KASIH}

Disampaikan kepada Dr. Ir. Rudi Nugroho, M.Eng, direktur Pusat Teknologi Lingkungan, yang berkenan memberi kesempatan kepada tim untuk menyelesaikan penelitian ini

\section{DAFTAR PUSTAKA}

1. Asaoka Tadatomo, "Yousui Haisui Shori Gijutsu “, Tokyo, 1973.

2. Benefiled, L.D., Judkins, J.F., and Weand, B.L., "Process Chemistry For Water And Waste Treatment", Prentice-Hall, Inc., Englewood, 1982.

3. Fair, G.M., Geyer, J.C., AND Okun, D.A., " Element Of Water Supply And Waste Water Disposal ", Second Edition, John Wiley And Sons, New York, 1971.

4. Hamer, M. J., " Water And Waste water Technology ", Second Edition, John Wiley And Sons, New York, 1986.

5. JICA : Water Supply Engineering Vol. I. Edited by Japan Water Work Association.1990.

6. Keputusan Menteri Kesehatan Republik Indonesia Nomor 907/MENKES/SK/VII/2002 tanggal 29 Juli 2002 tentang syarat-syarat dan pengawasan kualitas air minum

7. Peavy, H.S., Rowe, D.R, AND Tchobanoglous, S.G., "Environmental Engineering ", Mc Graw-Hill Book Company, Singapore, 1986.

8. Tatsumi Iwao, " Water Work Engineering (JOSUI KOGAKU) ", Japanese Edition, Tokyo, 1971.

9. Viessman W,JR., "Water Supply And Pollution Control ", fourth edition, Harper and Ror Publisher, New york, 1985.

10. Wong, J.M., "Chlorination-Filtration for Iron and Manganese Removal", Journal AWWA Vol.76, NO.1, January 1984.

11. H.K. Alluri et.al., "Biosorption: An ecofriendly alternative for heavy metal removal", African Journal of Biotechnology, vol. 6 (25) (pp. 2924-2931), 28 December 2007.

12. Metcalf and Eddy, 2004, Wastewater Engineering 4th edition, McGraw Hill International Editions, New York.

13. Asli Baysal, Nil Ozbek and Suleyman Akman (2013). Determination of Trace Metals in Waste Water and Their Removal Processes, Waste Water - Treatment Technologies and Recent Analytical Developments, Prof. Fernando Sebastián 
García Einschlag (Ed.), ISBN: 978-953-510882-5, InTech, DOI: 10.5772/52025.

14. https://www2.chemistry.msu.edu/courses/c em837/Anodic\%20Stripping\%20Voltammet ry.pdf (diakses 5 September 2014)

15. Standar Nasional Indonesia, 2009, Air dan air limbah - Bagian 4 : Cara uji besi (Fe) secara Spektrofotometri Serapan Atom (SSA) - nyala , SNI 6989.4: 2009

16. Standar Nasional Indonesia, 2004, Air dan air limbah-Bagian 11: Cara uji derajat keasaman $(\mathrm{pH})$ dengan menggunakan alat $\mathrm{pH}$ meter, SNI 06-6989.11-2004 